\title{
Comparative Analysis of Pejerrey Fish (Odontesthes bonariensis) Gonadal Development During Two Consecutive Spawning Seasons in Relation to Sex Steroids and Temperature Variation in Cochicó Lake (Pampas Region, Argentina)
}

\author{
Pamela Sabrina del Fresno ${ }^{1}$ (D) Darío César Colautti² (D), Gustavo Emilio Berasain ${ }^{3}$ (D), \\ Leandro Andrés Miranda ${ }^{1 *}$ (i)
}

\begin{abstract}
${ }^{1}$ Instituto Tecnológico de Chascomús, INTECH (CONICET-UNSAM), Laboratorio de Ictiofisiología y Acuicultura, Avenida Intendente Marino Km 8.200 (B7130IWA), Chascomús, Buenos Aires, Argentina.

2Instituto de Limnología “Dr. Raúl a. Ringuelet" ILPLA-(CONICET-UNLP), Boulevard 120, Casco Urbano, 1900 La Plata, Buenos Aires, Argentina.

32Dirección Provincial de Pesca. Ministerio de Agroindustria de la provincia de Buenos Aires.
\end{abstract}

\section{How to cite}

del Fresno, P.S., Colautti, D.C., Berasain, G.E., \& Miranda, L.A. (2021). Comparative Analysis of Pejerrey Fish (Odontesthes bonariensis) Gonadal Development During Two Consecutive Spawning Seasons in Relation to Sex Steroids and Temperature Variation in Cochicó Lake (Pampas Region, Argentina). Turkish Journal of Fisheries and Aquatic Sciences, 21, 347-355. http://doi.org/10.4194/1303-2712-v21_7_04

\section{Article History}

Received 22 December 2020

Accepted 08 April 2021

First Online 26 April 2021

\section{Corresponding Author}

Tel.: +542241430323 int. 111

E-mail: Imiranda@intech.gov.ar

\section{Keywords}

Atherinopsidae

Climate

Pampas lakes

Reproduction

Sex hormones

Testis-ova

\begin{abstract}
Cochicó belongs to "Encadenadas del Oeste" system of lakes being a typical water body of the Pampas region. The most abundant fish species in this lake is the pejerrey (Odontesthes bonariensis) valued due to the quality of its flesh and as a game fish. The aim of this study was to compare the gonadal stages of pejerrey during two consecutive spawning seasons (August to December) in relation to sexual steroids and temperature in this lake. In general, pejerrey gonadal development, the Gonadosomatic index and the plasma levels of estradiol and testosterone fluctuated in relation with temperature. In 2014 samplings, females started to ovulating in early August, with a peak during September-October and ending in December with many of them with atretic oocytes. However, in 2015, a marked delay in maturation was observed with ovulated fish only in October and December. This fact may be because the minors mean temperatures recorded in this year. For males, it was possible to find spermiating animals during the whole spawning season and only arrested animals in December. Unexpectedly, histological gonadal analysis revealed for the first time pejerrey with testis-ova, probably due to the intensive use of agrochemicals in this region.
\end{abstract}

\section{Introduction}

In the Pampas region of Argentina, the typical water bodies are shallow lakes. These lakes are commonly eutrophic environment with a high limnological variability. Some of them are permanent and others are temporary with periodic flooding and drought conditions (Diovisalvi et al., 2015). Because of these special characteristics, they are highly sensitive to climatic variation (Mooij et al., 2008; Jeppesen et al., 2010). In the last years, it was demonstrated that this region is experiencing a large-scale change in climate such as elevated temperatures, more abundant precipitations, and increased frequency of floods and droughts events (Berasain et al., 2015; Colautti et al., 2015; Elisio et al., 2015a; Elisio et al., 2018). Moreover, Pampas lakes are the natural habitat of a fish species with high biological and economic value, both for their commercial importance and for their sporting or recreational interest, the pejerrey Odontesthes bonariensis (Somoza et al., 2008).

One of the most important systems of the Pampas lakes, is "Encadenas del Oeste" localized in Buenos Aires Province, Argentina. This system marks the beginning of the productive area of the west of this province and is located in a climate transition zone from a sub-humid to 
semi-arid climate. The main lakes belonging to this system, presented from west to east are: Epecuén, del Venado, del Monte, Cochicó and Alsina. It is important to mention, that the lands surrounding these lakes are subjected to an intensive agricultural activity, highlighting the crops of drought-resistant cereals. In these lakes pejerrey is one of the most abundant fish, being its recreational fishing activity very important especially in Cochicó lake. This water body is an endorheic and eutrophic lake with a surface of approximately $40 \mathrm{~km}^{2}$, with diary oxygen deficit in depth, without permanent thermal stratification and it has been classified according to the soluble solid residue, as a body of mesohaline water to oligohaline.

It is known, that fish reproduction is regulated by different hormones and enzymes that jointly control the functioning of the brain-pituitary-gonad axis in order to stimulate gametogenesis and spawning (Lubzens et al., 2010). Besides, in temperate regions environmental cues (mainly photoperiod and temperature) modulate fish reproductive axis and thereby promote the spawning seasonality (Pankhurst \& Porter, 2003), as it was also demonstrated in pejerrey (Elisio et al., 2014; 2015b). It was reported in the wild that pejerrey is a multiple spawner with a major reproductive period at the end of the winter with a peak during spring and a minor one in autumn, depending of the environmental conditions (Elisio et al., 2014; 2015b). In females pejerrey it was observed that a new oocyte clutch starts to develop when the leading clutch approaches ovulation, being able to spawn frequently in short intervals of 20 to 30 days in captivity (Chalde et al., 2016; Chalde \& Miranda, 2020). In this specie, it was also demonstrated that the increase of water temperature and photoperiod modulate gametogenesis in Chascomús lake (Elisio et al., 2014; 2015b). Also, it has been reported that high temperatures above $23^{\circ} \mathrm{C}$ decreased sex steroids plasma levels, provoking a complete regression and spawning impairment (Soria et al., 2008; Elisio et al., 2012; Miranda et al., 2013).
It is important to mention that this system of lakes locates in the south west of Pampas region, was poorly studied, and also it has been recently observed a decrease in pejerrey population specially in Cochicó lake. In spite of the importance of this species as economic resource this is the first study that described the gonadal stages of pejerrey during two consecutive spawning seasons in relation with sex steroids and air temperature in Cochicó lake. The findings obtained can help government authorities to make decisions in order to manage this value natural resource.

\section{Materials and Methods}

\section{Study Area}

Cochicó lake belongs to a System of Pampas lakes that extends between the parallels $36^{\circ} 30^{\prime \prime}$ and $37^{\circ} 30^{\prime \prime}$ $\mathrm{S}$ and meridians $61^{\circ} 00^{\prime}$ and $63^{\circ} 30^{\prime} \mathrm{W}$ (Figure 1 ) in Guaminí county, in the south-west of Buenos Aires Province, Argentina. This system is well distinguished by a defined east - west gradient salinity from fresh to saline water.

\section{Animal Sampling}

Adult pejerrey of both sexes were sampled in Cochicó lake throughout the spawning season (August, October and December) in 2014 and 2015. A net gang composed by eight floating multifilament gill nets with a height of $1.3 \mathrm{~m}$, differing in lengths $(4.5 ; 7.4 ; 8.6 ; 13.4$; 20.2; 30.2; 45.4; and $70.2 \mathrm{~m}$ ), and mesh sizes (bar distance: $14,19,21,25,28,32,36$, and $40 \mathrm{~mm}$ ) was used (Berasain et al., 2015). All samplings were carried out at night, and the fish were taken alive to the Hydrobiology Station of Cochicó in the morning. Immediately, adult pejerrey were anesthetized with a bath of benzocaine (100ppm) and measured (Total Length; TL, Standard Length: SL in cm; Weight: W in g; Table 1). Only selected fish above the length of the first maturation $(>14 \mathrm{~cm}$ of

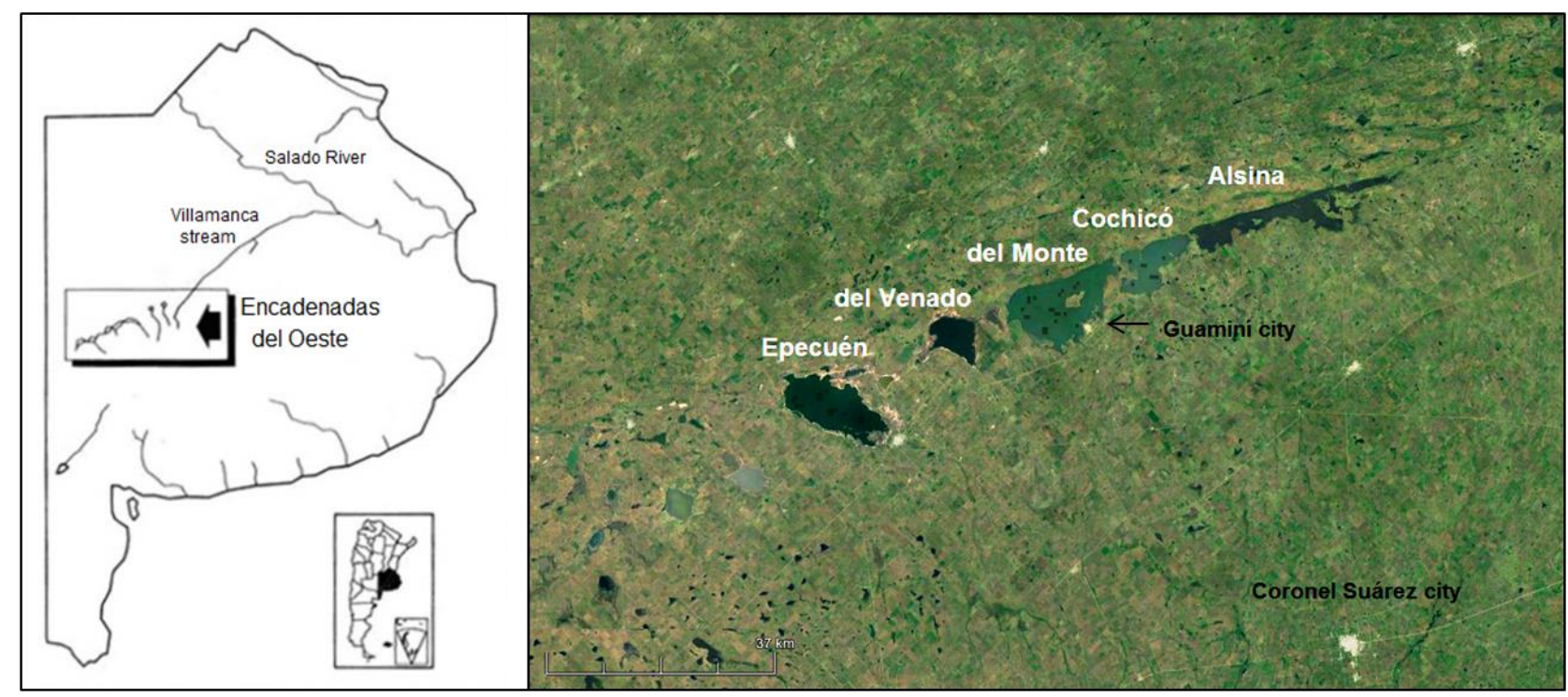

Figure 1: "Encadenadas del Oeste" System lakes, Buenos Aires, Argentina. 
SL) were used (Elisio et al., 2014). After this, blood samples were taken from the caudal vessels using heparinized syringes, and plasma samples were obtained by centrifugation at $4^{\circ} \mathrm{C}$ and stored at $-80^{\circ} \mathrm{C}$ for sex steroids measurements. Then, gonads were excised and weighted in order to calculate the gonadosomatic index (GSI = 100GW/W). After, a section of each gonad was fixed in formalin $10 \%$ and processed by routine methods for embedding in Paraplast Plus and posterior histological analysis.

All fish were handled and sacrificed in accordance with the UFAW Use and Care Committee Handbook on the Care and Management of Laboratory Animals (http://www.ufaw.org.uk/pubs.htm\#Lab) and local regulations.

\section{Histological Analysis}

Ovarian and testicles sections of $6 \mu \mathrm{m}$ thick were stained with hematoxylin and eosin for observation of histological characteristics and estimation of the reproductive status of each animal. Female gonad stages were defined following the guidelines proposed by Elisio et al. (2014): Primary growth (PG), cortical alveoli (CA), initial vitellogenesis $(\mathrm{VtgA})$, advanced vitellogenesis (VtgB), final maturation (FM), atretic (AT) and ovulated (OV).

Male gonadal stages were defined following the guidelines proposed by Elisio et al. (2015b): Arrested (A), spermatogonial stage (SG), spermatocytary stage (SC) and spermiogenic stage (SP). This last stage was reclassified in: Initial spermiogenic stage (ISP): 4-6 layers of spermatogonia (Spg); spermatogenic lobules well developed; testicular lumen is full of spermatozoa (Spz); GSI $1.8 \%$. Spermiogenic stage (SP): The number of Spg (2-3 layers) and spermatocytes (Spc) is relatively scarce. Most of spermatogenic lobules possess Spz. The testicular lumen is full of Spz; GSI: $~ 2 \%$. Final spermiogenic stage (FSP): 2-3 layers of Spg, spermatogenic lobules are less developed than in ISP and SP and full of spermatids (Spd) and Spz; testicular lumen has scarce Spz; GSI: 1\%.

The identification of the stages of both sexes was performed on micrographs taken with a light microscope Nikon Eclipse E600, equipped with a digital photomicrographic system (Nikon Digital Sight DS-Fi1).
Then, the percentages of gonadal stages of both sexes were calculated per each date of sampling.

\section{Sex Steroid Measurements}

The plasma levels of estradiol $\left(E_{2}\right)$ in females and testosterone $(T)$ in males were measured by an enzymelinked immunosorbent assay (ELISA), using commercial kits and following the manufacturer protocols (DRG International Inc., Mountainside, NJ, USA; E2: EIA-2693 and T: EIA-1559) previously validated by Chalde et al. (2016). Serum samples were extracted with diethylether and suspended in their initial volume of PBS buffer. A standard curve was run for each ELISA plate. The lower limits of detection were $9.7 \mathrm{pg} / \mathrm{mL}$ for $E_{2}$ and $83 \mathrm{pg} / \mathrm{mL}$ for T. The optical density was read at $450 \mathrm{~nm}$. The intra-assay coefficients of variance were $<10 \%$.

\section{Environmental Variables}

The air temperature and precipitation data were provided from the National Meteorological Service (Coronel Suarez, Buenos Aires Province, Argentina $37^{\circ}$ $28^{\prime} \mathrm{S}, 61^{\circ} 56^{\prime}$ O) 50 miles far from Cochicó lake. We decided to analyze these data instead of water temperature because this lake is $600 \mathrm{Km}$ far from INTECH and it was impossible to set up and equipment to record water temperature continuously. In Pampas shallow lakes it was demonstrated that water showed a tight coupling with air temperature, therefore suggesting that their thermal conditions depend largely on the local climate (Elisio et al., 2015a). Maximum, mean and minimum temperatures were calculated monthly from July to December. Mean annual precipitation $(\mathrm{mm})$ was calculated from daily data. Water salinity was measured in each sampling date using an optical refractometer (Atago Co, Tokyo, Japan) to the nearest of $0.1 \mathrm{~g} / 1$.

\section{Statistical Analysis}

Gonadosomatic indexes and hormonal profiles data are presented as the mean \pm standard error of the mean (SEM). Normal distribution for data was analyzed by the Shapiro-Wilk test, and the Levene test was used to check the homogeneity of variance. The differences

Table 1: Morphometric data of pejerrey captured in Cochicó Lake.

\begin{tabular}{|c|c|c|c|c|c|c|c|c|c|}
\hline \multirow[b]{2}{*}{ Year } & \multirow[b]{2}{*}{ Date } & \multicolumn{4}{|c|}{ Females } & \multicolumn{4}{|c|}{ Males } \\
\hline & & $\mathrm{SL}(\mathrm{cm})$ & $\mathrm{TL}(\mathrm{cm})$ & W (g) & $\mathrm{N}$ & $\mathrm{SL}(\mathrm{cm})$ & $\mathrm{TL}(\mathrm{cm})$ & W (g) & $\mathrm{N}$ \\
\hline \multirow{3}{*}{2014} & August $3^{\text {rd }}$ & $35.2 \pm 3.7$ & $41.3 \pm 3.9$ & $741.9 \pm 234.9$ & 12 & 41.5 & 35.3 & 641.0 & 1 \\
\hline & October $1^{\text {st }}$ & $14.8 \pm 0.8$ & $17.2 \pm 0.9$ & $30.3 \pm 3.6$ & 10 & $14.4 \pm 0.5$ & $16.7 \pm 0.6$ & $28.4 \pm 2.4$ & 10 \\
\hline & December $9^{\text {th }}$ & $14.9 \pm 0.6$ & $17.5 \pm 0.6$ & $32.2 \pm 2.1$ & 9 & $14.7 \pm 0.3$ & $17.3 \pm 0.4$ & $31.0 \pm 2.3$ & 6 \\
\hline \multirow{3}{*}{2015} & August $5^{\text {th }}$ & $18.9 \pm 1.4$ & $22.3 \pm 1.9$ & $80.3 \pm 23.7$ & 4 & $20.1 \pm 1.4$ & $23.6 \pm 1.6$ & $100.9 \pm 21.2$ & 10 \\
\hline & October $7^{\text {th }}$ & $17.6 \pm 7.7$ & $20.3 \pm 9.1$ & $101.4 \pm 191.5$ & 8 & $14.9 \pm 1.4$ & $17.4 \pm 1.6$ & $36.6 \pm 9.2$ & 10 \\
\hline & December $15^{\text {th }}$ & $15.6 \pm 0.7$ & $18.0 \pm 0.6$ & $39.4 \pm 3.9$ & 7 & $15.7 \pm 0.8$ & $18.1 \pm 0.8$ & $40.2 \pm 5.3$ & 10 \\
\hline
\end{tabular}

Total length (TL). Standard length (SL) and weight (W). Values are mean \pm Standard Deviation 
for these parameters were analyzed using one-way analysis of variance (ANOVA) followed by Tukey's multiple comparison test. The results were considered statistically significant at $P<0.05$. When the data lacked the assumptions of the statistical test, logarithmic transformations were used. Statistical analyses were performed using GraphPad Prism 5.0 Software and InfoStat Sofware.

\section{Results}

\section{Animal Sample Analysis}

The morphometric data and number of pejerrey captured in 2014 and 2015 of both sexes are shown in Table 1. The differences in fish sizes between samples dates may be due to the different areas where the nets were placed in the lake and to the segregation by sex at the peak of spawning (Elisio et al., 2014).

In August of 2014, some females were ovulated and the rest were at FM or at vitellogenic stages indicating the beginning of spawning. In October similar proportion of the same stages were observed, however, one atretic female was found. In December, most of females were atretic (70\%), the rest at FM stage and only one was at CA stage, indicating the end of reproductive period. In August of 2015, most females were at CA stage and one was vitellogenic. In October and December, similar proportion of OV (30\% - $45 \%)$ and AT females (10\%) females were found. A difference observed between these months was that in October the rest of them were at FM stage and in December the rest were at $\mathrm{VtgB}$ stage (Figure $2 \mathrm{~A}$ ).

The analysis of GSI and $E_{2}$ in 2014 showed the highest GSI values in August (7.2 $\pm 1.2 \%)$, and a slight decreased in October (3.8 $\pm 0.4 \%)$ and December $(4.5 \pm 0.3 \%)$. The $E_{2}$ plasma values were also high in August $(1051.0 \pm 200.9 \mathrm{pg} / \mathrm{ml})$ and in October $(801.2 \pm 105.1 \mathrm{pg} / \mathrm{ml})$, whereas a strong and statistically significant (ANOVA, $\mathrm{P}<0.05$ ) decline was observed in December (229.5 $\pm 11.8 \mathrm{pg} / \mathrm{ml})$. In 2015, the GSI showed a clear peak in October with a maximum value of $7.2 \pm 1.1 \%$ being statistically significant different when compared with the other months. For $E_{2}$ the highest levels were recorded in October and December (Figure 2B).

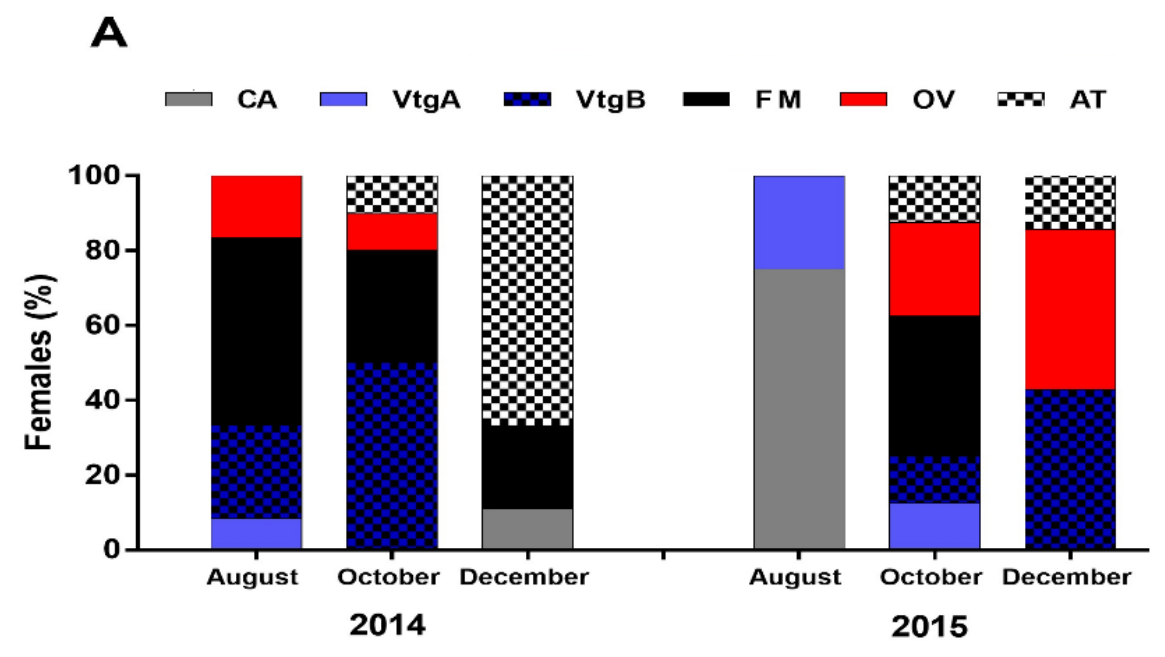

B

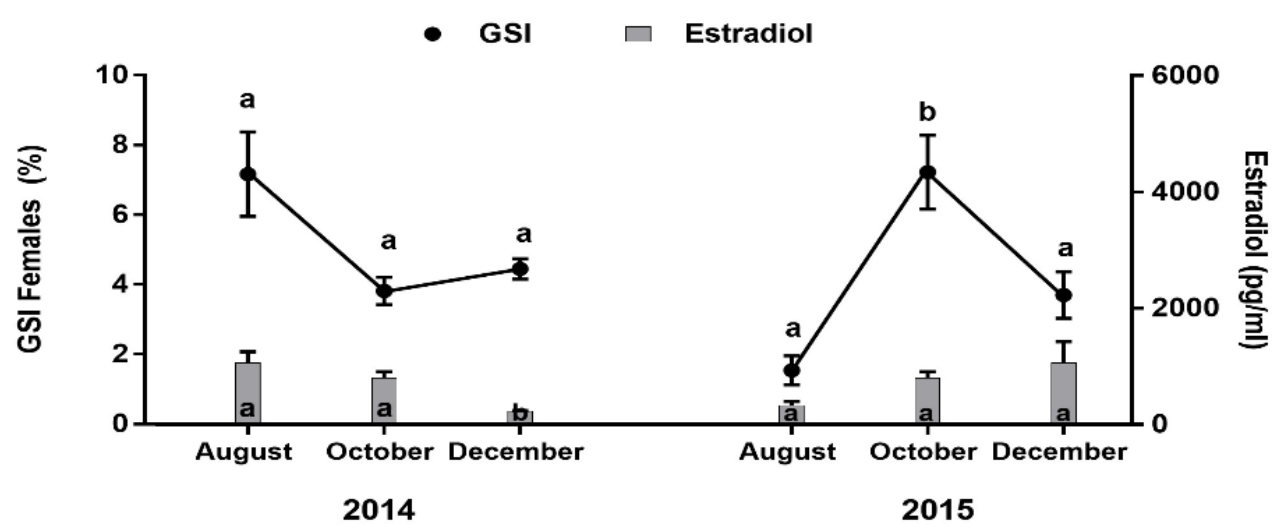

Figure 2. Pejerrey sampling in Cochicó Lake (2014 and 2015). A: Percentage of females at different gonadal stages. CA: cortical alveoli stage; VtgA: initial vitellogenesis stage; VtgB: advanced vitellogenesis stage; FM: final maturation stage; OV: ovulated females; AT: atretic stage. B: Gonadosomatic indexes (GSI: dots) and $E_{2}$ plasma levels (bars). Values are mean \pm SEM. Different letters represent significant differences between sampling dates (Tukey's multiple comparison test. $\mathrm{P}<0.05$ ). 
In the case of males, only 1 was caught at ISP stage in August of 2014, while in October most of them were at SP and FSP stages. In December, $50 \%$ were at FSP, and the rest were arrested or at SP stages showing the end of spermiation. In 2015, males caught in August were initiating the spermiation. In October, all males were easily releasing sperm ( $90 \%$ SP stage) and in December, most of them were at FSP stage and the rest were arrested (Figure $3 \mathrm{~A}$ ). The GSI and T plasma values were high in August 2014 (1.87\%, 2049.0 pg/ml, respectively) and in October $(1.55 \pm 0.1 \%, 588.8 \pm 133.3 \mathrm{pg} / \mathrm{ml})$ meanwhile a decreased was observed in December (1.3 $\pm 0.1 \%$., $401.1 \pm 57.6 \mathrm{pg} / \mathrm{ml}$,). In 2015, the highest GSI value was recorded in October $(2.0 \pm 0.1 \%)$ being statistically different (ANOVA, $\mathrm{P}<0.05$ ) with respect to the minor value recorded in December samples. For $T$, the highest level was found in August $(2042.1 \pm 70.3$ $\mathrm{pg} / \mathrm{ml}$ ) meanwhile minor and statistically significant values (ANOVA, $P<0.05$ ) were observed in October and December (Figure $3 \mathrm{~B})$.

Unexpectedly, the histological gonadal analysis revealed that one male of August and one male of October belonging to 2015 samplings, had oocytes without follicles cells scattered among and within testicular lobules (testis-ova; Figure 4).

\section{Environmental Variables}

The air temperatures were summarized in Table 2. In 2014, the mean air temperature ranged from $7.6 \pm 3.0^{\circ} \mathrm{C}$ (July) to $20.2 \pm 3.4^{\circ} \mathrm{C}$ (December). In addition, the absolute minimum varied from -4.1 to $3.8^{\circ} \mathrm{C}$ and the absolute maximum from 19.1 to $33.8^{\circ} \mathrm{C}$. In the case of 2015 , the mean air temperature ranged from $6.2 \pm 3.2^{\circ} \mathrm{C}$ (July) to $20.5 \pm 3.6^{\circ} \mathrm{C}$ (December), showing lower mean temperatures from July to October when compared with 2014 temperatures. Additionally, the absolute minimum varied from -5.5 to $3.7^{\circ} \mathrm{C}$ and the absolute maximum from 20.7 to $36.0^{\circ} \mathrm{C}$.

Annual rainfall varied from $1141.5 \mathrm{~mm}$ in 2014 to $925.4 \mathrm{~mm}$ in 2015. Water salinity ranged from 1 to 1.7 $\mathrm{g} / \mathrm{l}$ in 2014 and 1.8 to $2 \mathrm{~g} / \mathrm{l}$ in 2015 .

\section{Discussion}

This study described for the first time the reproduction status of pejerrey population from Cochicó lake using gonadal histology, GSI, sex steroids plasma levels during two consecutive spawning seasons. In general, it was observed that during the sampling periods the temperature did not present substantial

A

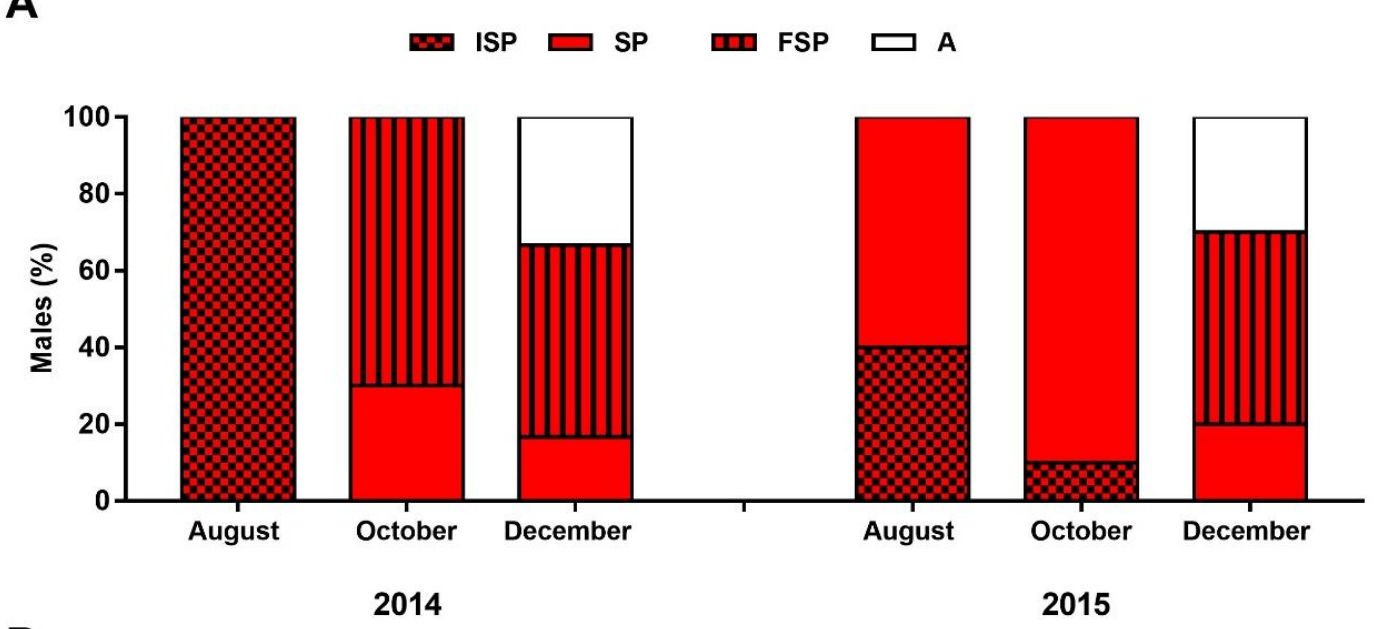

B

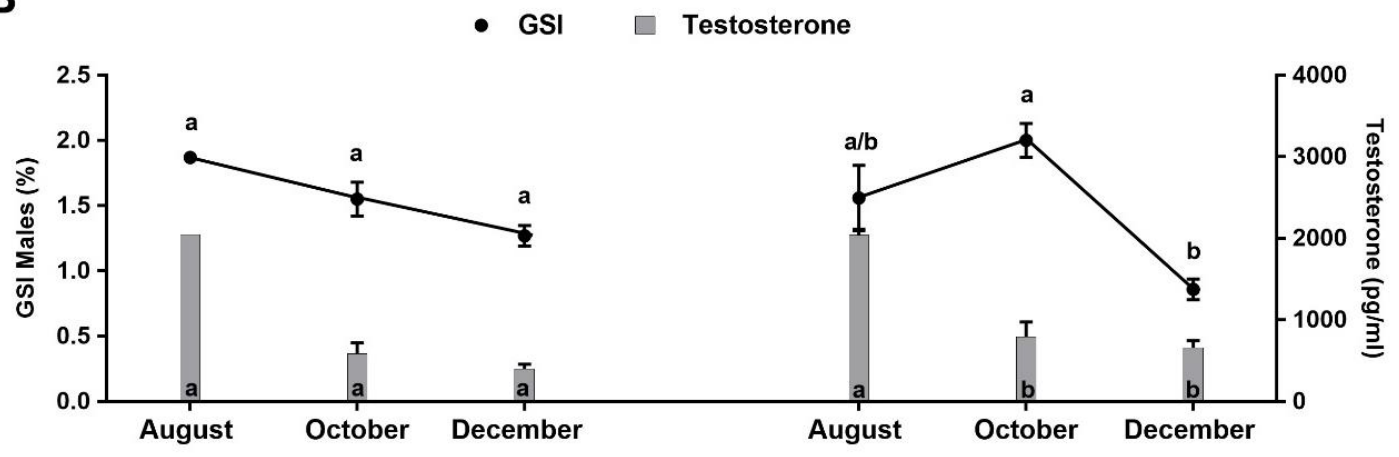

2014

2015

Figure 3: Pejerrey sampling in Cochicó Lake (2014 and 2015). A: Percentage of males at different gonadal stages. ISP: Initial spermiogenic; SP: spermiogenic; FSP: final spermiogenic; A: arrested. B: Male gonadosomatic indexes (GSI: dots) and T plasma levels (bars). Values are mean \pm SEM. Different letters represent significant differences between sampling dates (Tukey's multiple comparison test. $\mathrm{P}<0.05)$. 
variations. However, mean lower temperatures were recorded from July to October in 2015 when compared with 2014. Besides, the rainfall conditions were a little different modifying also the salinity of the water in the lake.

The pejerrey population of Cochicó lake showed a wide range of lengths, a cyclical and annual gonadal pattern of maturation with the presence of early juvenile in spring. In general, this study showed an increase of gonadal development pattern as temperature raises, associated to elevate GSI and $E_{2}$ and T plasma levels with a decreased of all these parameters in early summer with higher temperatures. In teleost, gonadal development and spawning are regulated through different hormones which controlled the reproductive axis (hypothalamus-pituitary-gonads; Zohar et al., 2010). Also, photoperiod and temperature are one of the most important factors that regulate fish reproductive cycle (Miranda et al., 2013).

It has been previously reported for Chascomús pejerrey population that spawning period started at the end of winter with a peak during spring (SeptemberOctober) and ended in November-December with water temperatures near $23^{\circ} \mathrm{C}$ (Elisio et al., 2014, 2015a). Similar results were obtained for Cochicó pejerrey population in 2014 samplings. However, in 2015 a marked delay in female maturation was observed since in August no ovulated fish were captured. Moreover, similar proportion of ovulated pejerrey were caught in October and December, with a few atretic animals. This fact may be because of the minors mean temperatures recorded from July to October in comparison with 2014 temperatures. In December samples, atretic females were captured, with a higher proportion in 2014. These observations indicated that the ovulation was ending associated to an increase of temperature during the end of spring, as it was reported by Elisio et al. (2014). It is known that in temperate teleost, the increase of water temperature during summer signals the end of reproductive episodes (Pankhurst \& Porter, 2003; Miranda et al., 2013).

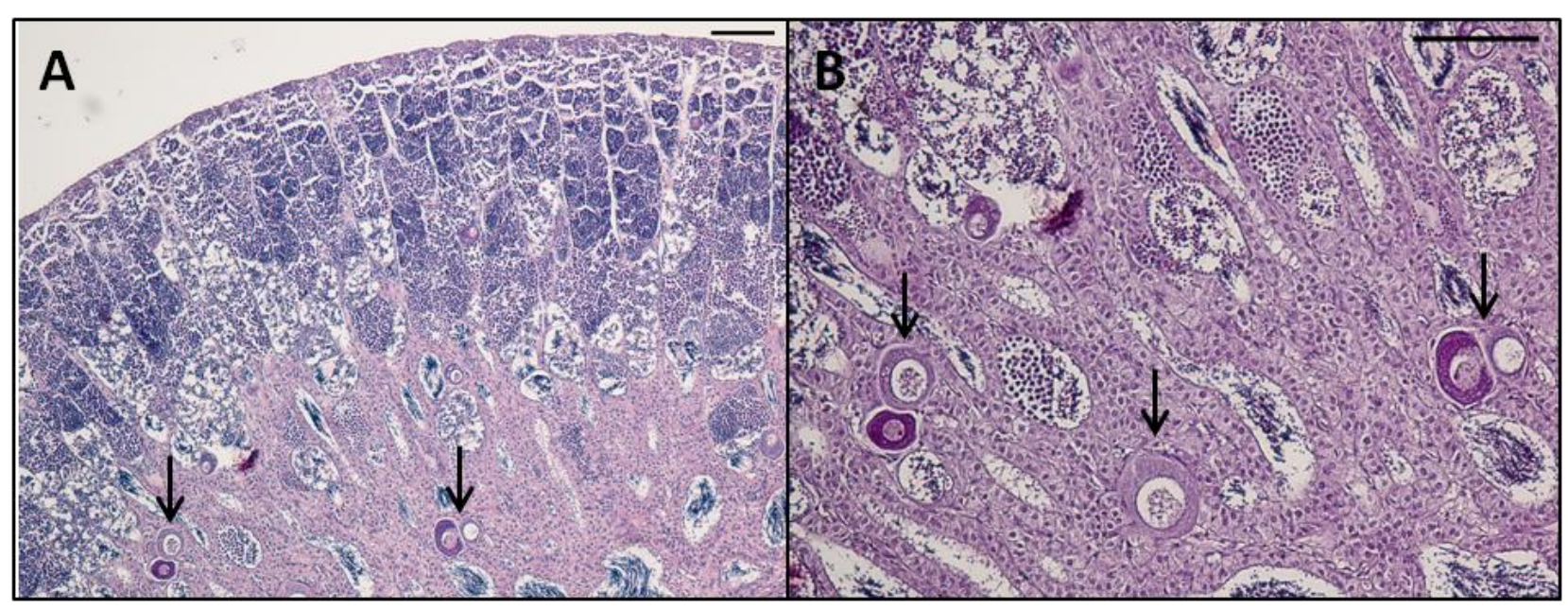

Figure 4. A: Transversal section of pejerrey testicles showing oocytes (black arrow) in testicular lumen. B: High magnification of A. Bar: $100 \mu \mathrm{m}$.

Table 2. Data of air temperature $\left({ }^{\circ} \mathrm{C}\right)$ recorded during pejerrey spawning season. National Meteorological Service (Coronel Suarez, Buenos Aires Province, Argentina).

\begin{tabular}{cccccccc}
\hline & \multirow{2}{*}{ Year } & \multicolumn{7}{c}{ Months } \\
\cline { 3 - 8 } Mean & 2014 & July & August & September & October & November & December \\
\hline \multirow{3}{*}{ Max. Mean } & 2015 & $6.2 \pm 3.0$ & $9.8 \pm 4.1$ & $11.9 \pm 2.0$ & $14.8 \pm 3.7$ & $16.8 \pm 3.8$ & $20.2 \pm 3.4$ \\
& 2014 & $12.5 \pm 3.3$ & $8.8 \pm 2.6$ & $9.1 \pm 2.4$ & $10.4 \pm 3.5$ & $17.0 \pm 2.5$ & $20.5 \pm 3.6$ \\
Min. Mean & 2015 & $13.2 \pm 3.6$ & $15.6 \pm 4.8$ & $18.2 \pm 2.8$ & $20.9 \pm 4.7$ & $23.9 \pm 5.3$ & $28.3 \pm 4.3$ \\
& 2014 & $2.6 \pm 4.2$ & $3.1 \pm 4.9$ & $16.6 \pm 3.4$ & $16.5 \pm 4.0$ & $24.7 \pm 2.8$ & $27.6 \pm 3.8$ \\
Abs. Max. & 2015 & $2.2 \pm 4.1$ & $3.9 \pm 3.1$ & $1.7 \pm 4.1$ & $4.4 \pm 4.4$ & $9.3 \pm 3.4$ & $13.3 \pm 4.3$ \\
& 2014 & 19.1 & 27.3 & 22.3 & 29.3 & 33.2 & 33.8 \\
Abs. Min. & 2015 & 20.7 & 23.4 & 22.8 & 24.2 & 29.2 & 36.0 \\
& 2014 & -4.1 & -4.0 & -0.6 & 2.3 & 4.5 & 3.8 \\
\end{tabular}

Max: maximum; Min: minimum; Abs: absolute. 
It was demonstrated that GSI increased proportionally with gonadal development associated with $E_{2}$ plasma levels, raising during vitellogenesis and declining before ovulation in several species as the Gilthead bream (Sparus aurata; Kadmon et al., 1985), the Channel catfish (Ictalurus punctatus; Kumar et al., 2000), Senegalese sole (Solea senegalensis; GarcíaLópez et al., 2007), Ballan wrasse (Labrus bergylta; Muncaster et al., 2010), the Waigieu seaperch (Psammoperca waigiensis; Pham et al., 2011), the River catfish (Hemibagrus nemurus; Adebiyi et al., 2013) among others (Lubzens et al., 2010).

In this context, our results showed that in 2015, GSI and $E_{2}$ plasma levels increased from August to October and declined in December evidencing the spawning from October. Similar results were obtained by Elisio et al. (2014) for pejerrey population in Chascomús lake and in captivity (Miranda et al., 2006; Chalde et al., 2014; Chalde et al., 2016). However, in 2014 the GSI value decreased from August to October (1 atretic female) meanwhile $E_{2}$ plasma levels, remained equal but with a significant reduction in December, evidencing the majority of atretic females.

In the case of pejerrey males, spermatogenesis occurs in a larger range of temperatures than in the oogenesis, because it was possible to find spermiating fish from August to December and in March and April in Chascomús lake (Elisio et al., 2015b). Our results showed that in August all pejerrey captured were releasing sperm, with mean air temperatures of $16.5 \pm 4.8$ and $15.6 \pm 3.4{ }^{\circ} \mathrm{C}$ respectively. These temperatures were similar to that reported for the starting of spermiation in the pejerrey of Chascomús lake (Elisio et al., 2015b). In October of 2014, the gonadal histology revealed that most of the fish were in FSP stage meanwhile in 2015 were in SP stage, indicating that the peak of spermiation in 2014 was earlier than in 2015. These findings coincide with the presence of ovulated females in this study and with that reported by Elisio et al. (2014, 2015b).

In December of both years, in addition to pejerrey at SP and FSP stages, several arrested fish were caught indicating the ending of the reproductive activity. As it was mentioned for females, during the month before the sampling date (November) maximum air temperatures were above $24^{\circ} \mathrm{C}$, being these temperatures higher than those that cause reproductive impairment in wild and captive pejerrey (Soria et al., 2008; Elisio et al., 2012; 2015b). Similar results were reported in other teleost species such as: the roach (Rutilus rutilus; Gillet \& Quétin, 2006), Atlantic salmon (Salmo salar; Pankhurst et al., 2011; Anderson et al., 2012), Atlantic cod (Gadus morhua; Tveiten, 2008) among others (Miranda et al., 2013).

In general, male GSI values increased proportionally with gonadal development jointly with $T$ and 11-KT plasma levels (Miranda et al., 2007; Schultz et al., 2010). There have been several studies showing that $11-\mathrm{KT}$ is the androgen most active in stimulate the spermatogenesis (Miura et al., 1991; Ohta et al., 2007;
Schultz et al., 2010; Zohar et al., 2010), while T plays an integral role in stimulating both hypothalamic and pituitary functions (Miranda et al., 2007; Schultz et al., 2010; Zohar et al., 2010). Our findings showed that in 2014 the GSI value and T plasma levels decreased from August to December evidencing that the peak of spermiation was in August. In 2015 maximum values of T were measured in August and for GSI were recorded in October meanwhile a decrease of those parameters occurred in December jointly with the presence of arrested males. This trend indicated that the peak of spermiation was in October coincidentally with gonadal histological data.

According our knowledge there are no reports on the presence of pejerrey testis-ova in the wild. As it was mentioned, the lands surrounding "Encadenas del Oeste" lake system are subjected to an exhausted agricultural activity with an intensive use of agrochemicals such as atrazine. It has been demonstrated, that atrazine had negative effects on reproductive functions in fish (Spano et al., 2004; Tillitt et al., 2010; Papuolias et al., 2014). For example, the fathead minnow (Pimephales promelas) and cunner (Tautogolabrus adspersus) exposed to atrazine produced fewer eggs and testicular oocytes than control fish (Tillitt et al., 2010). However, other endocrine disruptors could cause similar adverse effects on male fish reproduction (Tyler et al., 1996; Dietrich \& Krieger, 2009; Sumpter \& Jobling, 2013; Gárriz et al., 2017; Norris et al., 2018). In this way it has been recently demonstrated that the exposure to Cadmium produced testis-ova in pejerrey (Gárriz et al., 2019).

In conclusion, it was demonstrated that pejerrey population is vulnerable to climate variability (specially temperature variations) and human pollution, and future investigations are needed to clarify these issues to protect this emblematic fish species and to develop an integrated management of Cochicó lake.

\section{Ethical Statement}

All fish were handled in accordance with the UFAW Use and Care Committee Handbook on the Care and Management of Laboratory Animals (http://www.ufaw.org.uk/pubs.htm\#Lab) and local regulations.

\section{Funding Information}

This study was supported by grants to L.A.M. (ANPCyT: PICT 2012-1537; 2017-2506), National Geographic Society (WW-233R-17).

\section{Author Contribution}

M.L.A: Conception, design and funding.

M.L.A., D.C.C., G.E.B., del F.P.S: Acquisition, analysis and interpretation of data.

M.L.A., del F.P.S., D.C.C: Manuscript writing. 


\section{Conflict of Interest}

The authors declare that they have no conflict of interest.

\section{Acknowledgements}

The authors thank Marcelo Schwerdt and Dante Saad for their assistance during the samplings.

\section{References}

Adebiyi, F.A., Siraj, S.S., Harmin, S.A., \& Christianus, A. (2013). Plasma sex steroid hormonal profile and gonad histology during the annual reproductive cycle of river catfish Hemibagrus nemurus (Valenciennes, 1840) in captivity. Fish Physiology \& Biochemistry. 39, 547-557. https://doi: 10.1007/s10695-012-9718-x

Anderson, K., Swanson, P., Pankhurst, N., King, H., \& Elizur, A. (2012). Effect of thermal challenge on plasma gonadotropin levels and ovarian steroidogenesis in female maiden and repeat spawning Tasmanian Atlantic salmon (Salmo salar). Aquaculture. 334-337, 205-212. https://doi: 10.7717/peerj.3898

Berasain, G.E., Colautti, D.C., Lenicov, M.R., Argemi, F., Bohn, V.Y., \& Miranda, L.A. (2015). Impact of water salinity on Odontesthes bonariensis (Actinopterygii, Atherinopsidae) fisheries in Chasicó Lake (Argentina). Hydrobiologia. 752, 167-174. https://doi.org/10.1007/s10750-014-1980-8

Chalde, T., Elisio, M., \& Miranda, L.A. (2014). Quality of pejerrey (Odontesthes bonariensis) eggs and larvae in captivity throughout spawning season. Neotropical Ichthyology. 12, 629-634. http://dx.doi.org/10.1590/1982-0224-20130146

Chalde, T., Gárriz, Á., Sánches, E.A., \& Miranda, L.A. (2016). Influence of pejerrey Odontesthes bonariensis (Valenciennes, 1835) broodstock age on gamete quality, reproductive performance and plasma sex steroid levels during the spawning season. Aquaculture Research. 47, 969-982. https://doi.org/10.1111/are.12555

Chalde, T., Miranda, L.A. (2020). Reproductive parameters of the native pejerrey fish (Odontesthes bonariensis) reared under natural temperature and light conditions. Aquaculture Research. 51, 706-711. https://doi: 10.1111/are.14517

Colautti, D.C., Baigún, C., Llompart, F., Maiztegui, T., García de Souza, J., Solimano, P., Balboni. L., \& Berasain, G. (2015). Fish assemblage of a Pampean shallow lake, a story of instability. Hydrobiologia. 752, 175-186. http://dx.doi.org/10.1007/s10750-014-2062-7

Dietrich, D.R., \& Krieger, H.O. (2009). Histological Analysis of Endocrine Disruptive Effects in Small Laboratory Fish. John Wiley and Sons, New Jersey.

Diovisalvi, N., Bohn, V.Y., Piccolo, M.C., Perillo, G.M.E., Baigún., C.R.M., \& Zagarese H.E. (2015). Shallow lakes from the Central Plains of Argentina: an overview and worldwide comparative analysis of their basic limnological features. Hydrobiologia. 752, 5-20. http://dx.doi.org/10.1007/s10750-014-1946-x

Elisio, M., Chalde, T., \& Miranda, L.A. (2012). Effects of short periods of warm water fluctuations on reproductive endocrine axis of the pejerrey (Odontesthes bonariensis) spawning. Comparative Biochemistry \& Physiology. 163, 47-55. http://dx.doi.org/10.1016/j.cbpa.2012.05.178

Elisio, M., Chalde, T., \& Miranda, L.A. (2014). Seasonal changes and endocrine regulation of pejerrey (Odontesthes bonariensis) oogenesis in the wild. Comparative Biochemistry \& Physiology. 175:102-109.

http://dx.doi.org/10.1016/j.cbpa.2014.05.020

Elisio, M., Vitale, A., \& Miranda, L.A. (2015a). Influence of climate variations on Chascomús shallow lake thermal conditions and its consequences on the reproductive ecology of the Argentinian Silverside (Odontesthes bonariensis Actinopterygii, Atherinopsidae). Hydrobiologia. 752, 155-166. http://dx.doi.org/10.1007/s10750-014-1945-y

Elisio, M., Chalde, T., \& Miranda, L.A. (2015b). Seasonal changes and endocrine regulation of pejerrey (Odontesthes bonariensis) spermatogenesis in the wild. General \& Comparative Endocrinology. 221, 236-243. http://dx.doi.org/10.1016/j.ygcen.2015.01.011

Elisio, M., Vera, C., \& Miranda, L.A. (2018). Influences of ENSO and PDO phenomena on the local climate variability can drive extreme temperature and depth conditions in a Pampean shallow lake affecting fish communities. Environmental Biology of Fish. 101, 653-666. http://dx.doi.org/10.1007/s10641-018-0726-2

García-López, A, Couto, E., Canario, A.V.M., Sarasquete, C., \& Martínez-Rodríguez, G. (2007). Ovarian development and plasma sex steroid levels in cultured female Senegalese sole Solea senegalensis Kaup. Comparative Biochemistry \& Physiology. 146, 342-354. ttp://dx.doi.org/10.1016/j.cbpa.2006.11.014

Gárriz, Á., del Fresno, P.S., \& Miranda, L.A. (2017). Exposure to $E_{2}$ and $E_{2}$ environmental concentrations affect different components of the Brain-Pituitary-Gonadal axis in pejerrey fish (Odontesthes bonariensis). Ecotoxicology Environmental \& Safety. 144, 45-53. http://dx.doi.org/10.1016/j.ecoenv.2017.06.002

Gárriz, Á, del Fresno, P.S., Carriquiriborde, P., \& Miranda, L.A. (2019). Effects of heavy metals identified in Chascomús shallow lake on the endocrine-reproductive axis of pejerrey fish (Odontesthes bonariensis). General \& Comparative Endocrinology. 273, 152-162. http://dx.doi.org/10.1016/j.ygcen.2018.06.013

Gillet, C., \& Quétin, P. (2006) Effect of temperature changes on the reproductive cycle of roach in Lake Geneva from 1983 to 2001. Journal of Fish Biology. 69, 518-534. https://doi.org/10.1111/j.1095-8649.2006.01123.x

Jeppesen, E., Meerhoff, M., Holmgren, K., Jensen, J.P., Mortensen, E., \& Hansen, A.M. (2010). Impacts of climate warming on lake fish community structure and potential effects on ecosystem function. Hydrobiologia. 646, 73-90. https://doi.org/10.1007/s10750-010-0171-5

Kadmon, G., Yaron, Z., \& Gordin, H. (1985) Sequence of gonadal events and oestradiol levels in Sparus aurata (L.) under two photoperiod regimes. Journal of Fish Biology. 26, 609-620. https://doi.org/10.1111/j.1095-8649.1985.tb04301.x

Kumar, R.S., Ijiri, S., \& Trant., J.M. (2000). Changes in the expression of genes encoding steroidogenic enzymes in the channel catfish (Ictalurus punctatus) ovary throughout a reproductive cycle. Biology of Reproduction. 63, 1676-1682. https://doi.org/10.1095/biolreprod63.6.1676

Lubzens, E., Young, G., Bobe, J., \& Cerdá, J. (2010). Oogenesis in teleosts: How fish eggs are formed. General \& 
Comparative Endocrinology. 165, 367-389. https://doi.org/10.1016/j.ygcen.2009.05.022

Miranda, L.A, Chalde, T., Elisio, M., \& Strüssmann, C.A. (2013) Effects of global warming on fish reproductive endocrine axis, with special emphasis in pejerrey Odontesthes bonariensis. General \& Comparative Endocrinology. 192, 45-54. https://doi.org/10.1016/j.ygcen.2013.02.034

Miranda, L.A, Strüssmann, C.A, Guilgur, L.G., \& Somoza, G.M. (2007). Cloning of FSH- $\beta$, LH- $\beta$ and glycoprotein hormone $\alpha$ subunits in pejerrey Odontesthes bonariensis (Valenciennes): Expression profile and relationship with GnRH expression and plasma sex steroid levels in male fish. Journal of Fish Biology. 71, 1571-1589. https://doi.org/10.1111/j.1095-8649.2007.01621.x

Miranda, L.A, Berasain, G.E., Velasco, C.A.M., Shirojo, Y.S., \& Somoza, G.M. (2006). Natural spawning and intensive culture of pejerrey Odontesthes bonariensis juveniles. Biocell. 30, 157-162.

Miura, T., Yamauchi, K., Takahashi, H., Nagahama. Y. (1991). Involvement of steroid hormones in gonadotropininduced testicular maturation in male Japanese eel (Anguilla japonica). Biomedical Research. 12, 241-248. https://doi.org/10.2220/biomedres.12.241

Mooij, W.M., De Senerpont Domis, L.N., \& Hülsmann, S. (2008). The impact of climate warming on water temperature, timing of hatching and young-of-the-year growth of fish in shallow lakes in the Netherlands. Journal of Sea Research. 60, 32-43. https://doi.org/10.1016/j.seares.2008.03.00

Muncaster, S., Andersson, E., Kjesbu, O.S., Taranger, G.L., Skiftesvik, A.B., \& Norberg, B. (2010). The reproductive cycle of female Ballan wrasse Labrus bergylta in high latitude, temperate waters. Journal of Fish Biology. 77, 494-511. https://doi.org/10.1111/j.1095-8649.2010.02691.x

Norris, D.O., Bolden, A.L., \& Vajda, A.M. (2018). The occurrence of intersex fishes in Boulder Creek, Colorado, is a recent phenomenon. General \& Comparative Endocrinology. 265, 56-60. https://doi.org/10.1016/j.ygcen.2017.12.001

Ohta, T., Miyake, H., Miura, C., Kamei, H., Aida, K., \& Miura, T. (2007). Follicle stimulating hormone induces spermatogenesis mediated by androgen production in Japanese eel, Anguilla japonica. Biology of Reproduction. 77, 970-977. https://doi.org/10.1095/biolreprod.107.062299

Pankhurst, N.W., King, H.R., Anderson, K., Elizur, A., Pankhurst, P.M., \& Ruff, N. (2011). Thermal impairment of reproduction is differentially expressed in maiden and repeat spawning Atlantic salmon. Aquaculture. 316, 7787. https://doi.org/10.1016/j.aquaculture.2011.03.009

Pankhurst, N.W., Porter, M.J.R. (2003). Cold and dark or warm and light: Variations on the theme of environmental control of reproduction. Fish Physiology \& Biochemistry.
28, 385-389.

https://doi.org/10.1023/B:FISH.0000030602.51939.50

Papoulias, D.M., Tillitt, D.E., Talykina, M.G., Whyte, J.J., \& Richter, C.A. (2014). Atrazine reduces reproduction in Japanese medaka (Oryzias latipes). Aquatic Toxicology. 154, 230-239.

https://doi.org/10.1016/j.aquatox.2014.05.022

Pham, H.Q., Nguyen, A.T., Kjørsvik, E., Nguyen. M.D., \& Arukwe, A. (2011). Seasonal reproductive cycle of Waigieu seaperch (Psammoperca waigiensis). Aquaculture Research. 43, 815-830. https://doi.org/10.1111/j.1365-2109.2011.02894.x

Schulz, R.W., França, L.R., Lareyre, J.J., Le Gac, F., ChiariniGarcia, H., Nóbrega, R.H., \& Miura, T. (2010). Spermatogenesis in fish. General \& Comparative Endocrinology. 165, 390-411. https://doi.org/0.1016/j.ygcen.2009.02.013

Somoza, G.M., Miranda, L.A., Berasain, G.E., Colautti, D., Remes Lenicov, M., \& Strüssmann, C.A. (2008). Historical aspects, current status and prospects of pejerrey aquaculture in South America. Aquaculture Research. 39, 784-793. https://doi.org/10.1111/j.1365-2109.2008.01930.x

Soria, F.N., Strüssmann, C.A., \& Miranda, L.A. (2008). High Water Temperatures Impair the Reproductive Ability of the Pejerrey Fish Odontesthes bonariensis: Effects on the Hypophyseal-Gonadal Axis. Physiology Biochemistry \& Zoology. 81, 98-905. https://doi.org/10.1086/588178

Spanò, L., Tyler, C.R., Van Aerle, R., Devos, P., Mandiki, S.N.M., Silvestre, F., Thomé. J.P., \& Kestemont, P. (2004). Effects of atrazine on sex steroid dynamics, plasma vitellogenin concentration and gonad development in adult goldfish (Carassius auratus). Aquatic Toxicology. 66, 369-379. https://doi.org/10.1016/j.aquatox.2003.10.009

Sumpter, J.P., \& Jobling, S. (2013). The occurrence, causes, and consequences of estrogens in the aquatic environment. Environmental Toxicology \& Chemistry. 32, 249-251. https://doi.org/10.1002/etc.2084

Tillitt, D.E., Papoulias, D.M., Whyte, J.J., \& Richter, C.A. (2010). Atrazine reduces reproduction in fathead minnow (Pimephales promelas). Aquatic Toxicology. 99, 149-159. https://doi.org/10.1016/j.aquatox.2010.04.011

Tveiten, H. (2008). Temperature influence on reproductive development and gamete quality in Atlantic cod (Gadus morhua). Cybium. 32, 195.

Tyler, C., Van der Eerden, B., Jobling, S., Panter, G., \& Sumpter, J. (1996). Measurement of vitellogenin, a biomarker for exposure to oestrogenic chemicals, in a wide variety of cyprinidfish. Journal of Comparative Physiology. 166, 418-426.

Zohar, Y., Muñoz-Cueto, J.A., Elizur, A., Kah, O. (2010). Neuroendocrinology of reproduction in teleost fish. General \& Comparativd Endocrinology. 165, 438-455. https://doi.org/10.1016/j.ygcen.2009.04.017 